\title{
Management of solid waste from health services according to the National Solid Waste Policy: a study conducted in the South of the Brazil
}

\author{
Gerenciamento dos resíduos sólidos da saúde conforme a Política \\ Nacional de Resíduos Sólidos: um estudo realizado no Sul do \\ Brasil
}

\author{
Rafael Vieira Mathias ${ }^{1}$ (D) \\ ${ }^{1}$ Universidade Federal de Santa Catarina - UFSC, Departamento de Administração de Empresas, Área de \\ Concentração Produção e Desenvolvimento, Florianópolis, SC, Brasil. E-mail: rafaelvmathias@gmail.com
}

How to cite: Mathias, R. V. (2021). Management of solid waste from health services according to the National Solid Waste Policy: a study conducted in the South of the Brazil. Gestão \& Produção, 28(4), e5727, https://doi.org/10.1590/1806-9649-2021v28e5727

\begin{abstract}
The management of waste from health services is considered an extremely controversial topic and widely discussed because it is mainly about contaminated materials. This study aims to analyze the waste management of health services in hospitals in a southern region of Brazil, identifying the final disposal processes, in accordance with the National Solid Waste Policy, describing the management and practices in each link of the final destination chains and estimation of the volume of post-consumer waste generated. For this, it was necessary to describe the management and practices in each link of the chains, estimate the volume of waste generated, identify the reverse logistics chains and the final destination of the post-consumer waste from the health services. In addition to evaluating the feasibility of reusing hospital waste, taking into account the technical standards and legislation present in the National Solid Waste Policy and in organizations such as the National Agency for Health Surveillance, the Brazilian Association of Technical Standards, the National Council of the Environment and the National Nuclear Energy Commission. The National Solid Waste Policy brought an information framework already contained in other norms and resolutions in force, before its publications, determining the objectives that have not yet been fully met in the investigated region.
\end{abstract}

Keywords: Waste management; Waste from health services; National solid waste policy; Reverse chain.

Resumo: O gerenciamento dos resíduos de serviços na saúde é considerado um assunto extremamente polêmico e amplamente discutido por se tratar, em sua maioria, de materiais contaminados. Esse estudo possui a finalidade de analisar a gestão de resíduos dos serviços de saúde em instituições hospitalares de uma região do Sul do Brasil, identificando processos de destinação final, conforme a Política Nacional de Resíduos Sólidos, descrevendo o gerenciamento e as práticas em cada elo das cadeias de destinação final e estimando o volume dos resíduos de pós-consumo gerados. Para isso, foi necessário descrever o gerenciamento e as práticas em cada elo das cadeias, estimar o volume dos resíduos gerados, identificar as

Received: Sept. 16, 2019 - Accepted June 1, 2020

Financial support: None.

This is an Open Access article distributed under the terms of the Creative Commons Attribution License, which permits unrestricted use, distribution, and reproduction in any medium, provided the original work is properly cited. 
cadeias de logística reversa e a destinação final dos resíduos de pós-consumo de serviços da saúde. Além de avaliar a viabilidade de reaproveitamento dos resíduos hospitalares, considerando as normas técnicas e as legislações presentes na Política Nacional de Resíduos Sólidos e em órgãos como a Agência Nacional de Vigilância Sanitária, a Associação Brasileira de Normas Técnicas, o Conselho Nacional do Meio Ambiente e a Comissão Nacional de Energia Nuclear. A Política Nacional de Resíduos Sólidos trouxe um arcabouço de informações já contidas em outras normas e resoluções vigentes, anteriores às suas publicações, determinando metas que ainda não foram cumpridas em sua totalidade na região pesquisada.

Palavras-chave: Gerenciamento de resíduos; Resíduos de serviços da saúde; Política Nacional dos Resíduos Sólidos; Cadeia reversa.

\section{Introduction}

Population growth, associated with the increase in per capita income benefited products, is accentuated in the world. However, after a while these same products become unusable due to obsolescence, depreciation, defects or technological updates. This relationship between population growth and the transformation of natural resources into consumer products is only a problem when the volume of waste resulting from society's demand increases, disproportionately, when compared to population growth (Cunha \& Caixeta-Filho, 2002).

Faced with this problem, the Brazilian federal government has been subsidizing actions and projects to minimize environmental, social and economic problems resulting from inadequate solid waste management.

In 2010, the National Policy for Solid Waste (NPSW) was instituted with the objective of preserving public health and environmental quality, regarding the nongeneration, reduction, recycling and treatment of solid waste, stimulating standards in the production and consumption of goods and services, among other actions that may give better destination to Urban Solid Waste (USW) and Health Services Waste (HSW). The HSW, which is contained in the MSW, is differentiated by the potential risks to the population's health, by the possibility of contamination of the environment and by allowing work accidents in several professionals, besides being difficult to reuse.

The management of waste from health services is considered a controversial issue and widely discussed because it is mostly contaminated material. Produced at all stages of human activities, waste, in terms of both composition and volume, varies according to consumption practices and production methods. Several laws have been established to determine who is responsible for this type of waste, from generation to final disposal. These sources of waste require technical, environmentally safe, feasible solutions for collect, conditioning, storage, treatment and final disposal.

The HSW, when inadequately managed in any of its handling processes, can cause impacts, polluting water, soil and air, altering chemical, physical and microbiological environmental factors. In the southern region of Brazil, about 1,095 municipalities out of a total of 1,191 , provide services related to the managements of HSW, totally or partially (ABRELPE, 2014). A collection rate of $0.423 \mathrm{~kg} / \mathrm{hab} . / y e a r$ is estimated, of which $52.8 \%$ are autoclaving methods, $43.2 \%$ incineration, $2.3 \%$ microwave and $1.7 \%$ other types of methods (ABRELPE, 2018).

The analysis of reverse management and disposal of health waste will provide the academy with a systemic and integrated view of the problem of discarded materials. It will be possible to understand how each act in the chain is responsible for the waste, 
from its generation to final disposal. Knowing this network demands a systematic and replicable scientific method, expanding the applications (Ciplet, 2006).

Therefore, this study analyzes the waste management of health services in hospital institutions in a southern region of Brazil, identifying the processes of final destination, according to the NPSW. Describing the management and practices in each link of the final destination chains, estimating the volume of post-consumption waste generated.

\section{NPSW conceptualization}

In practice, there is a distinction of behavior in health facilities, as in municipalities, where all waste is considered and segregated as hazardous or nothing is separated (Pereira et al. 2013). The NPSW is systematized with a relationship between government, companies and NGOs/society, on the activities with waste of different origins. Among the common actions of these agents are: integrated management; monitoring; environmental education; reverse logistics; 3R; and selective collection systems.

Several activities foreseen in the NPSW require the performance of one or two organizations of this tripartite, where the governmental ones are the centralizers of incentives and inspection, as schematized in Figure 1.

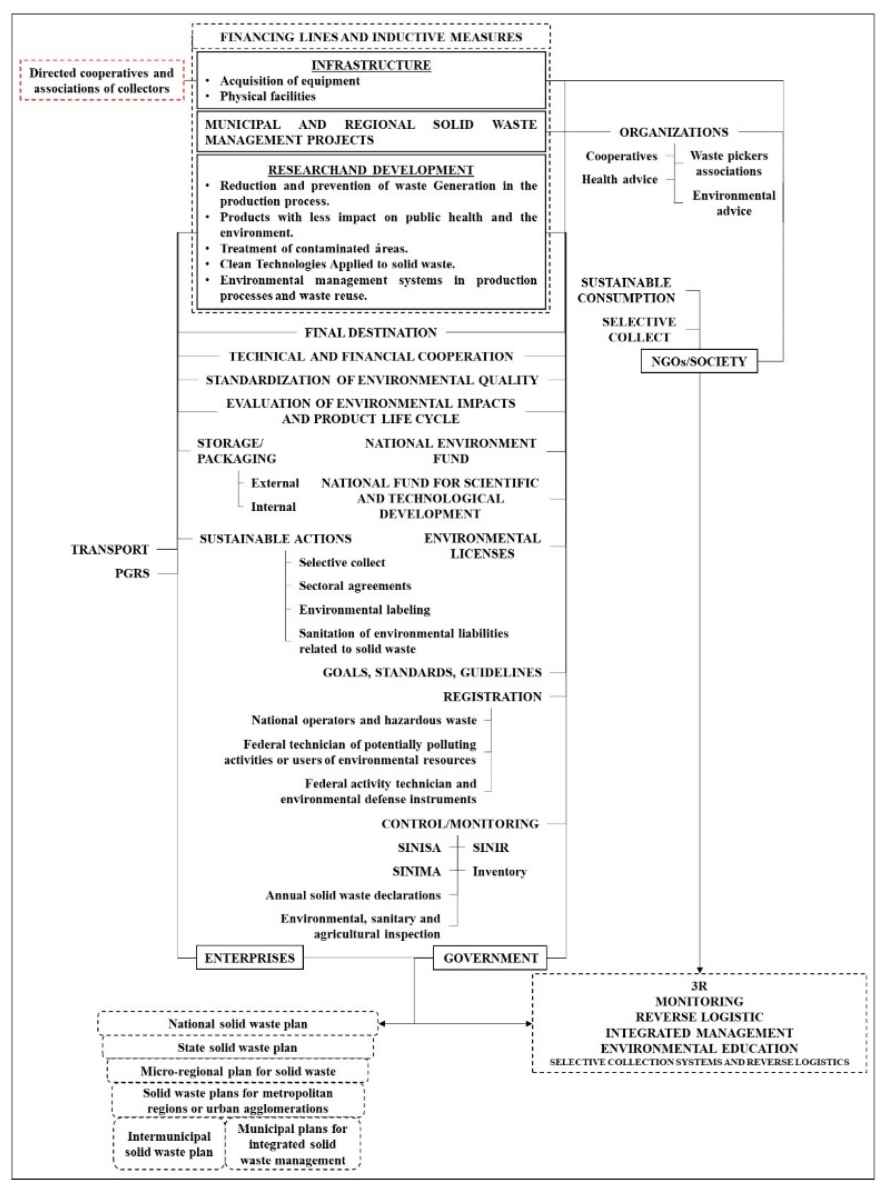


The conceptual map presented in Figure 1 demonstrates the actions foreseen in the NPSW and their sharing among government, company and society/NGOs, as well as the individual responsibilities.

In the political sphere, management has advanced in the form of a collegiate, with social participation, establishing local, regional and national councils. Thus, micro and macro perspectives for waste analysis are adopted. The micro perspective addresses the nodes of the waste cycle at the municipal or micro region level, while the macro perspective considers state and federal territoriality.

The micro regional approach provides advantages such as increasing the correct final destination and minimizing investment costs, providing the sharing of expenses between city, as well as greater agility in the implementation of solutions. This means that municipalities with low waste generation and few resources can join together to build sorting centers, composting and landfills.

The civil construction, agro industry and health sectors, among others, have obtained greater prominence over the discarded material, considering that USW are composed by resources of added value, being necessary the creation of new business sources (Garcia \& Zanetti-Ramos, 2004).

According to Pereira \& Pereira (2011), the planning foreseen in the NPSW is the first step to add value to waste, through plans, strategic planning and scenario analysis, situational diagnoses, proposing goals, programs and normalizations. The Waste Management Plan (PGR), associated to the health and civil construction waste generators, required modifications in its traditional scope that included hazardous waste generators, non-domestic waste and companies that transport these that, until then, followed diffuse government guidelines.

The PGR is an integral step in the environmental licensing process for enterprises or other activities that require environmental authorizations governed by the National Environmental System (NES) and approved by municipal bodies. The NPSW consolidates the scope and destination of the numerous instruments that already exist as a primary source (Law 12,305/2010).

The NPSW makes reverse logistics a national prerogative, determining that importers, manufacturers, distributors and traders of a given branch of activity, adopt actions and procedures that enable the collection and reuse of solid waste by the business sector, using them in their production cycle or in their final destination environmentally correct. According to NPSW, reverse logistics will operate in the following chains: batteries, tires, fluorescent lamps, sodium and mercury vapor and mixed light bulbs, lubricating oils, their residues and packaging, agrotoxic products and packaging, and packaging resulting from dangerous products, complying with the management standards established by SISNAMA, SNVS and SUASA, among other technical standards.

With the new technologies emerging for reuse and transformation, other chains are expected to be incorporated in the future. The very definition dealt with in Law no. $12,305 / 2010$, for reverse logistics, proposes this extension of the scope. The reverse logistics system provides a database through inventories, the National System of Information on Solid Waste Management (SINIR), the National System of Information on Waste Management (SINISA) and annual declarations, registrations and licensing, resulting in a waste bank and facilitating the creation of eco-efficient parks, where waste from business activity becomes raw material, promoting an industrial symbiosis.

The NPSW was originated by Decree No. 7404/2010 of December 23, 2010, which created the International Committee of the NPSW, being part of it the Ministries of 
Environment, Cities, Social Development, Fight Against Hunger, Health, Mines and Energy, Finance, Planning, Budget and Management, Development, Industry and Foreign Trade, Agriculture, Livestock and Supply, Science and Technology and the Secretariat of Institutional Relations of the Presidency of the Republic. According to the aforementioned decree, the committee is responsible for the actions set forth in Law No. 12, 305, Article 15 (Brasil, 2010a). This text reaffirms collective responsibility in waste management including domestic generators through packaging, collection and return.

The obligations stablished in the reverse logistics systems will be subject to penalty, warning and application of a fine in the amount of $R \$ 50.00$ to $R \$ 500.00$, in cases of recurrence or provisiono f services aimed at environmental preservation, improvement and recovery (Brasil, 2008).

For waste and packaging from activities requiring the handling of pesticides, in addition to the information contained in Law No. 7802 of 11 July 1989 (Brasil, 1989) and Decree No. 4074 of 4 January 2002 (Brasil, 2002), the reverse logistics system is also considered, for which Decree No. 7404/2010 (Brasil, 2010b) brings other observations.

As prescribed in this decree, all solid waste management and management will have to prioritize: reduction; non-generation; reuse; recycling; treatment of solid waste; and environmentally adequate final disposal of waste.

In addition, it must prioritize the participation of cooperatives and other associations of collectors of recyclable and reusable materials, composed of low-income individuals, valuing the social role of reverse logistics.

The incentives for initiatives provided for in Article 42 of Law no. 12,305 of 2010 (Brasil, 2010a) consider tax incentives, the destination of recyclable waste to associations and cooperatives and the granting of credits.

In view of this conceptualization of the NPSW, by assigning responsibilities to the government, companies and NGOs/society, a debate and questioning is allowed on how these agents should assume such attributions on the waste chain.

\section{Methodologies}

The research can be characterized as quantitative and qualitative. Quantitative because it measures the average potential of the waste coming from establishments that provide health services, and qualitative because it addresses issues related to the reverse management of the respective waste in accordance with the laws, regulations and standards in force for the management, collection and final disposal.

According to Miguel (2012), the combination of approaches is justified by several authors for the complementarily of methodological conceptions of scientific research. This will result in a better understanding of the problem proposed in the research than each would allow in isolation.

The data were collected by a structured instrument that relates the interview technique via questionnaire and on-site observation to confirm certain points about the stages of waste management (generation, segregation, conditioning, transportation and final destination).

Thus, the survey relied on the collection of primary data, in addition to the use of questionnaires, on-site observation, manuals and internal management reports of the researched establishments (hospitals, companies, NGOs, cooperatives that offer 
collection, transportation and final disposal work and HSW and secondary data from government agencies, diagnostics, reports and publications.

The questionnaire was made available online through the survey software, Survio@, which provides a platform for data collection and initial information of certain surveys. The link to the questionnaire was made available by e-mail to the person in charge of the institutions approached, being one of the tools of the software that restricts responses by Internet Protocol, reducing (IP) the possibility of duplicity of responses. The access can be made with any internet browser (Microssoft $囚$ Explorer, Firefox, and Chrome, among others). The answers were aggregated by the system in an online spreadsheet and can be compiled with Microsoft@Excel.

The questionnaire is composed of closed, open and multiple choice questions in order to seek information that would meet the objectives of this research in a sustainable manner and in accordance with the assumptions for reverse chain of the HSW covered in the theoretical review.

The secondary data were obtained through the survey of documents from the State Secretariat of Sustainable Development/State Council of the Environment of Santa Catarina (SDS/Consema), the State Secretariat of Health of Santa Catarina (SES/SC), the Superintendence of Health Surveillance (SUV), State Foundation of the Environment (Fatma), Brazilian Association of Public Cleaning and Special Waste (Abrelpe) and Institute of Applied Economic Research (IPEA). In addition to reading articles originated from research carried out in the Coordination for the Improvement of Higher Education Personnel (CAPES) periodical portal, as well as books and legislation that discuss the subject under investigation.

Regarding SES/SC, the data came from the Santa Catarina HSW generator registry and from the first diagnosis made in 2012, with the purpose of establishing information for State Plan for Integrated Solid Waste Management (Pergis/SC). This information provided an initial overview regarding the NPSW, and it was necessary to relate pertinent information with initial data, so that the municipalities could start preparing their respective plans.

The information contained in Pergis may be improved, updated and complemented by means of resolutions, reports, diagnoses and management manuals of the HSW in Santa Catarina, SDS/Consema, SUV and Fatma.

Fatma has the register of all sanitary landfills and dumps existing in the state of Santa Catarina, as well as information about the residues that are deposited in these places, among other resolutions on the management and disposal of urban waste.

Other relevant sources of secondary data were the portals of institutions linked to the municipalities of all municipalities, seeking information on waste planning, monitoring the establishment and compliance with the targets set out in the NPSW.

Abrelpe conducts panoramas on service offerings and the general volume of waste generated nationwide. The most recent panoramas used in this survey are from 2018, made available in Abrelpe's own website, and present a detailed survey on the general conditions of waste in Brazil.

In order to calculate the recycling potential on the reuse of waste, the research on the payment of urban environmental services for solid waste management, prepared by IPEA (2010), makes an analysis of the gains with recycling compared to obtaining inputs on the primary raw material, i.e., direct from nature.

Thus, the first procedure carried out on the data was the consolidation of the answers saved in the softwareSurvio $®$, in the xls file format (Microssoft@Excel). As much as the software provided previous information about the collected data, a deeper 
and more detailed analysis was necessary to have access to more specific information about the HSW of the survey participants.

Although all establishments, be they hospitals, companies, NGOs and cooperatives, answered the questionnaire faithfully to the questions, visits were necessary to observe certain procedures and locations, respecting the privacy and organizational rules of the establishments.

The data obtained through manuals, reports, legislation, among others, were transformed into statistical information, which were completed along with the quantitative data, since they were assigned descriptive statistical methods.

It is important to note that, in the matter of measurements on the average potential volume of HSW generation, we worked with the average volume of hospitals in a certain region of southern Santa Catarina, both by type of residue and number of operating beds.

\subsection{Researched region}

The State of Santa Catarina, to coordinate, expand and strengthen the administrative, economic and social capacity of the municipalities, was divided into micro regions, thus creating the Associations of Municipalities, today in number 21.

With this, the State promotes the establishment of inter-municipal and intergovernmental cooperation, aiming at the Integrated Regional Development of each Region, observing the deficiencies and exploring their potentialities.

The Municipal Associations of the State of Santa Catarina are registered institutions with legal personality under private law, recognized as institutions of public utility, nonprofit and with its own statute, each one having its respective structure.

The South of Santa Catarina is divided into three regions identified according to the associations of municipalities: Municipalities Association of the Laguna Region (AMUREL), Municipalities Association of the Carboniferous Region (AMREC) and Municipalities Association of the Extreme South of Santa Catarina (AMESC).

In order to delimit a region to be the target of this survey, a combination of numbers of municipalities in the region, population, health establishments, Unified Health System (SUS), and the number of existing hospitals was defined along with information from Brazilian Institute of Geography and Statistics (IBGE). The result is summarized in Figure 2.

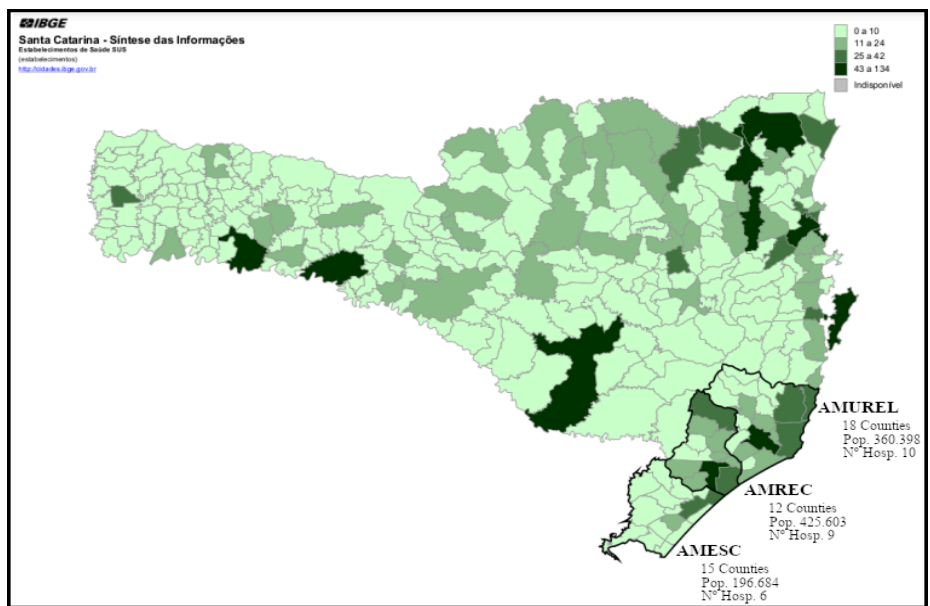

Figure 2. Date compilation from the Southern Regions of Santa Catarina (IBGE, 2016). 
According to Figure 2, the mapping conducted by IBGE (2016) of health facilities in South Santa Catarina shows a greater concentration in the AMUREL and AMREC regions, as well as their population volume. However, the number of municipalities and hospitals associated to the SUS was determinant for choosing the target region of this survey. Thus, the geographical basis for the survey was the AMUREL region, located in the South of the State, comprising a total of eighteen municipalities and totaling a population of 360,398 inhabitants.

Another characteristic that influenced the choice of the region researched is that $90 \%$ of the municipalities do not have the Waste Management plan of Health Services (PGHSW) or are in the process of preparation and constitution (FECAM, 2019), as prescribed in Law no. 12,305/2010 (Brasil, 2010a).

The recognition of the research site brought subsidies and guidance for the planning of data collection.

\subsection{Researched establishments}

To meet the objectives of this survey, which refers to the entire reverse chain of HSW and its agents, the establishments were divided into three groups, as can be seen in Figure 3.

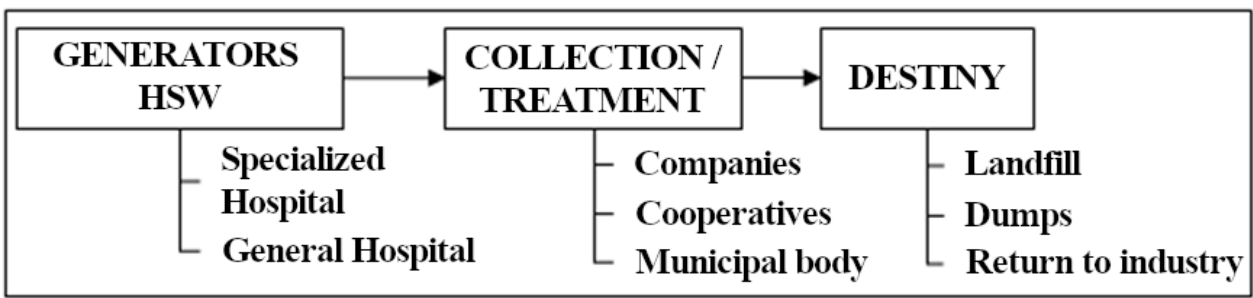

Figure 3. Research groups. The Author 2019.

The group of HSW generators are ten hospitals, defined in two types according to the understanding below, DataSUS (2018):

- Specialized Hospital: hospital designed to provide health care in a single specialty/area. It may have an Emergency/Emergency Service and the Therapeutic Diagnostic Support Service (SADT). It may or may not have an Integrated System of Patrimony, Administration and Contracts (SIPAC), usually of regional, macro regional or state reference;

- General Hospital: hospital destined to provide assistance to basic activities, by professionals and/or other medical specialties. It may have Emergency/Emergency service and must also have SADT of medium complexity, being able to have or not SIPAC.

The preference for hospitals and not for other health establishments present in the National Cadastre definitions is justified by the fact that they have greater representativeness in the generation of HSW, as well as in the amplitude of the processes that involve their management. On the other hand the preference of hospitals that attend SUS, for attending a larger patient's volume than private hospitals. Generally, hospitals that provide services through SUS attend other health plans, and do not perform a restriction on patients; in addition, according 
to guidelines contained in Law No. $8080 / 1990$, every Brazilian is entitled to medical care protected by SUS (Brasil, 1990).

The group regarding the collection and treatment seeks to define external aspects and procedures of the establishments regarding HSW. The data and analyses of this group refer to the companies, cooperatives and municipal agencies that provide the service of collection, transport and external treatment of the HSW. These, in turn, direct the waste to the best destination, which may be recycling, elimination through incineration/autoclave and, finally, final destination in landfills and/or dumps.

The last group comprises the destination of the HSW directed by external collectors, which dispose of these HSW in landfills or open dumps. As in the case of disposal or recycling, the waste is not disposed of at a certain final destination and is not subscribed to at this stage of the chain because it is a disposition of reuse.

It is important to note that incineration/self-cleaning processes result in waste that needs to be disposed of properly, such as ashes and other compositions that may be destined for other purposes.

\section{Presentation and results analysis}

In this topic, the presentation of results and their analysis from on-site observation, access to internal reports and interviews with teams of health professionals will be prepared, according to the methodology employed.

Although hospitals belong to the same region, they have different characteristics from their history to their financing and care structure. Of these, all have surgical centers, $50 \%$ have ICU, 30\% neonatal/infant (mixed) ICU, $20 \%$ hemodialysis, which includes high complexity services. This impacts on the quantity and diversity of residues generated, which include: cotton, disposable syringes, disposable bodies, ampoules, needles, paper towels, plastic bottles of serum, paper (printed, cardboard, newspapers, packaging, napkin, cardboard boxes), toilet paper, plastic bottles, scalps, probes, disposable compress, polyvinyl chloride (PVC) equipment, glass bottles, plastic bags, aluminum cans, plaster, food waste (employees and patients) wooden spatulas, anatomical parts, amputated limbs and others produced in these types of establishments.

The rate referring to the volume of HSW generation is determined by the average of residues generated per day with the amount of beds, resulting in a comparative parameter. The potential amount of residue generation is closely linked to the activities developed in health establishments, depending on the level and technological capacity of the services offered, specialties, volume of patients attended, among other peculiarities that may influence the generation of HSW.

Table 1 shows the quantification of the waste according to the number of beds, the averages of the common waste and the averages of the potentially infective and sharp-hole waste. 
Table 1. HSW quantification by sector.

\begin{tabular}{|c|c|c|c|c|c|c|}
\hline SECTOR & $\begin{array}{l}\text { Numbers } \\
\text { of beds }\end{array}$ & $\begin{array}{c}\text { Potentially } \\
\text { infectious } \\
\text { waste } \\
\text { (kg/day) }\end{array}$ & $\begin{array}{c}\text { Common } \\
\text { waste } \\
\text { (kg/day) }\end{array}$ & $\begin{array}{l}\text { Sharps } \\
\text { (kg/day) }\end{array}$ & $\begin{array}{c}\text { Total } \\
\text { (kg/day) }\end{array}$ & $\begin{array}{c}\text { Generation } \\
\text { Rate } \\
\text { (kg/bed/day) }\end{array}$ \\
\hline Adult ICU* & 25 & 17.58 & 21.87 & 1.50 & 40.95 & 1.64 \\
\hline $\begin{array}{c}\text { Neonatal/ Infant } \\
\text { ICU }\end{array}$ & 12 & 6.68 & 11.68 & 0.50 & 18.86 & 1.57 \\
\hline Coronary ICU & 7 & 2.07 & 11.16 & 0.90 & 14.13 & 2.02 \\
\hline Surgery Center & 196 & 53.68 & 176.93 & 11.76 & 242.37 & 1.24 \\
\hline Isolation & 4 & 10.29 & 1.47 & 2.31 & 14.07 & 3.52 \\
\hline $\begin{array}{l}\text { Reverse } \\
\text { insulation }\end{array}$ & 4 & 11.04 & 1.05 & 2.10 & 14.20 & 3.55 \\
\hline $\begin{array}{l}\text { Pre and post } \\
\text { operative }\end{array}$ & 36 & 8.83 & 32.36 & 2.36 & 43.55 & 1.21 \\
\hline Pediatrics & 78 & 8.54 & 31.05 & 0.20 & 39.79 & 0.51 \\
\hline Hospitalization & 420 & 149.07 & 409.88 & 30.73 & 589.68 & 1.40 \\
\hline Emergency & 35 & 16.99 & 21.03 & 2.78 & 40.81 & 1.17 \\
\hline $\begin{array}{l}\text { Maternity/ } \\
\text { Obstetries }\end{array}$ & 104 & 15.68 & 56.94 & 3.30 & 75.92 & 0.73 \\
\hline Drugstore & & & 7.24 & & 7.24 & \\
\hline Administration & & & 7.34 & & 7.34 & \\
\hline $\begin{array}{l}\text { Kitchen and } \\
\text { dining room }\end{array}$ & & & 180.76 & & 180.76 & \\
\hline TOTAL & 921 & 300.45 & 970.77 & 58.44 & $1,329.66$ & 1.44 \\
\hline
\end{tabular}

* Acronym used to refer to the Intensive Care Unit, a sector in health establishments that receive critically ill patients.

Table 1 shows that the areas considered critical (ICU, Pediatrics, Isolation, and Surgical Center) had higher rates of waste generation than the others. This is due to the nature of the activities performed in these sectors, where a greater number of daily interventions are performed in patients, using several disposable materials such as: needles, transfusion bags, equipment, syringes, diapers, dressings, among others.

Materials such as equipment, bags and diapers, after being used, retain biological material such as urine, blood and leftovers of liquid drugs. Due to this, the weight of these HSW increases, even if the volume is maintained.

According to the surveyed establishments, $70 \%$, states that the HSW management plan is disseminated by sectors and employees regardless of profession and status. Of the total number of sites surveyed, $80 \%$ claimed to have PGHSW; however, other data show several counterpoints to this statement.

For $40 \%$ of establishments, the PGHSW was still in the early stages of development. Only $20 \%$ admitted that the PGHSW were already written and validated by responsible professionals, foreseeing actions to reduce the volume generated, among other specifications that meet the National Environmental Council (CONAMA) resolution 358/05 (Brasil, 2005) and Collegiate Resolution Board of Directors (RDC) 306/2004 (Brasil, 2004).

For every management process, it is important that the establishment has a responsible manager. Of the establishments, $80 \%$ reported having technical responsible for the elaboration, revision, implementation and training of personnel on Program Solid Waste Management. 
However, no PGHSW was presented in the survey when the on-site observation and analysis of reports and documents of the establishments regarding the management of the HSW. This data does not support the statement that the establishments do not carry out adequate procedures for their HSW, but attests to the lack of a document foreseen as a target in the NPSW.

\subsection{Proceedings and internal practices}

At all stages of HSW management, important information can be identified that refer to the reverse chain within the health facilities studied. Already in the segregation of waste, diversified care is observed, established in accordance with existing norms, laws and resolutions.

In general, the residues are basically conditioned in containers per group. Group A waste is deposited in milky white bags, with the proper identification of potentially infectious waste, and each subgroup is directed to the specific treatment determined by law, as shown in Figure 4.

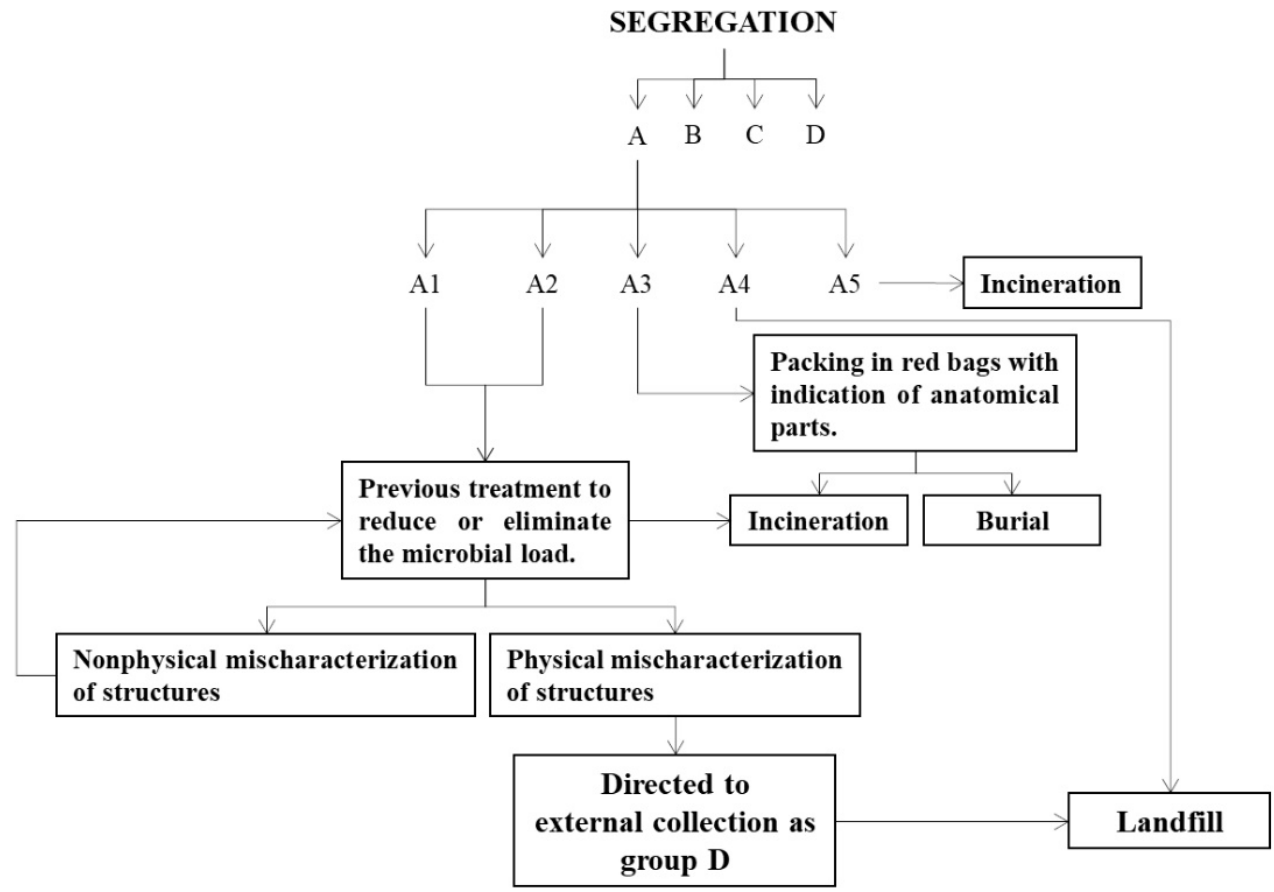

Figure 4. Group A wastes management.

As shown in Figure 4, no Group A waste is destined or stored for purposes other than land filling or external treatment by incineration. Waste from Group $B$, as well as Group A, has subgroups as shown in Figure 5. 


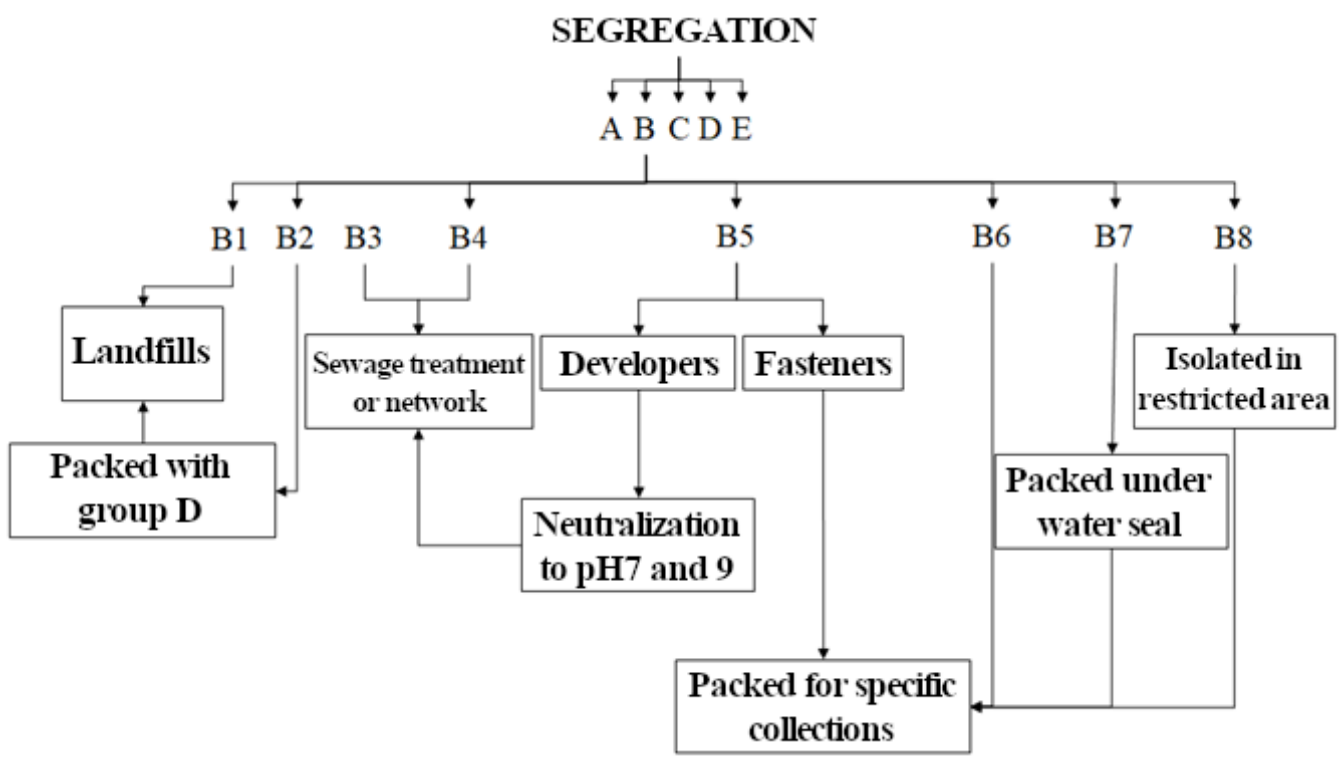

Figure 5. Group B wastes management.

The HSW of group B are distinguished in liquid or solid medicines that can be discarded together with the residues of group $A$, being sanitizers and excreta of patients treated with anti-neoplastic chemotherapy, which are eliminated in the sewage system together with the developers used in radiology after a $\mathrm{pH}$ neutralization treatment. Other wastes are considered dangerous to the environment and public health, for this reason they are conditioned in these facilities for collections performed by specific companies.

Group C waste in the researched establishments had three characteristics: solid waste, liquid waste and contaminated puncture material. For all of them, differentiated management is performed, as shown in Figure 6.

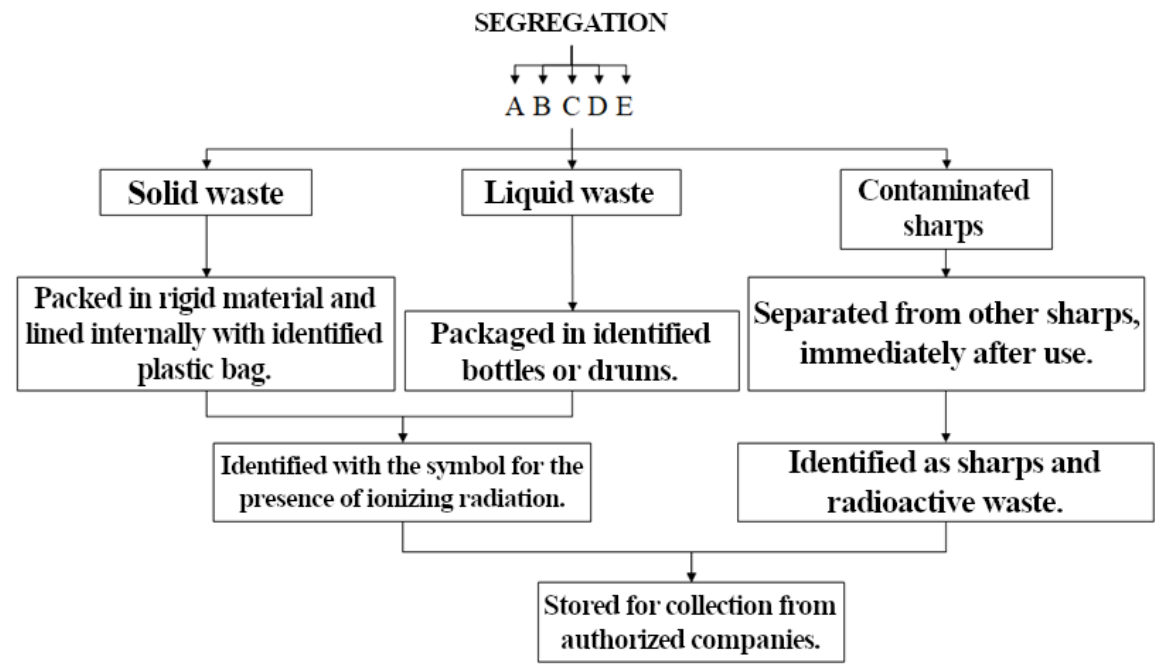

Figure 6. Group $\mathrm{C}$ wastes management. 
Both materials and waste from group $C$ are handled by trained professionals, where the use of PPE is mandatory. The waste is stored for collection from specific companies, or by the suppliers themselves, in locations different from other groups and summarily protected and controlled.

Group D, as it does not present any biological, chemical or radiological risk, does not undergo any specific treatment or handling. As much as all the establishments have stated that they promote segregation by paper, metal glass, plastic, organic waste, only $10 \%$ of them direct recycling or reuse. These wastes are usually stored, waiting for the companies that provide MSW collection services for the municipalities.

For the establishments that direct to recycling or reuse, the management follows the form of segregation shown in Figure 7.

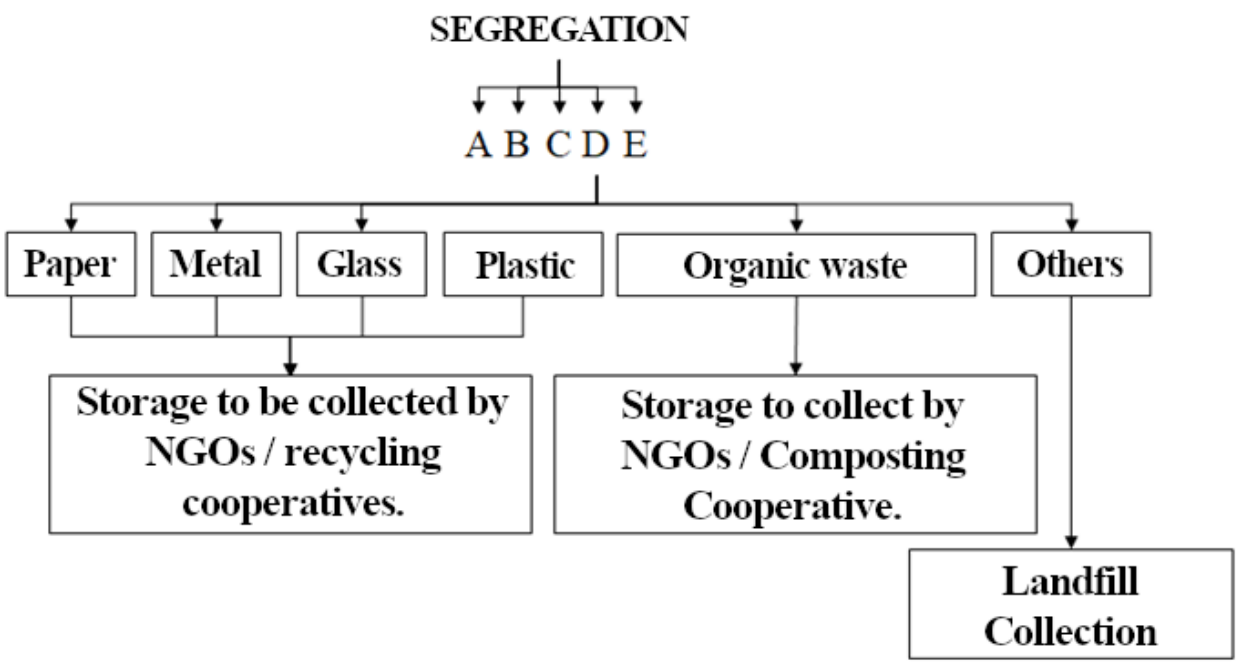

Figure 7. Group D wastes management.

The waste from this group, regardless of its characteristics, is packed in black bags. The primary packaging of medicines and sanitizing products are also discarded in this group.

Group E materials are highly disposable and cannot be reused. After use, they are immediately packaged in rigid containers that resist puncture and leakage, with a lid and properly identified with the international symbol of biological risk.

Storage, internal and external transports are carried out together with Group A containers. Generally, the waste from this group is destined for landfills.

Internal transport is a procedure that takes waste from the generation site to external storage. Of the establishments studied, $80 \%$ had internal collection with separate containers, which differentiated the HSW from common waste. The percentage of $90 \%$ of the establishments uses identification symbols of the internal collectors, packages, containers and storage sites as a prerequisite for internal transportation.

All the establishments studied claimed to have exclusive outlets for waste, an important measure that prevents the risk of accidents and increases safety against contamination (Brasil, 2006). About $70 \%$ of the establishments have containers used for transport and conditioning, in addition to the internal waste transit measures provided for in items 1.4.1 and 1.4.2 of RDC 306 (Brasil, 2004). 
According to the data collected, around $50 \%$ of the establishments have internal temporary shelter and $70 \%$ have external shelter. These data depend greatly on the size of the hospital and its ability to dispatch the HSW quickly to external storage. This in turn is extremely important to avoid animal access and exposure of the community that frequents these environments.

\subsection{Collecting and external transport}

In the process of external collection and transportation, HSW are separated and identified as infectious, chemical or common waste. Figure 8 demonstrates how the management of the collection and transportation of HSW is performed at AMUREL facilities, observed on site.

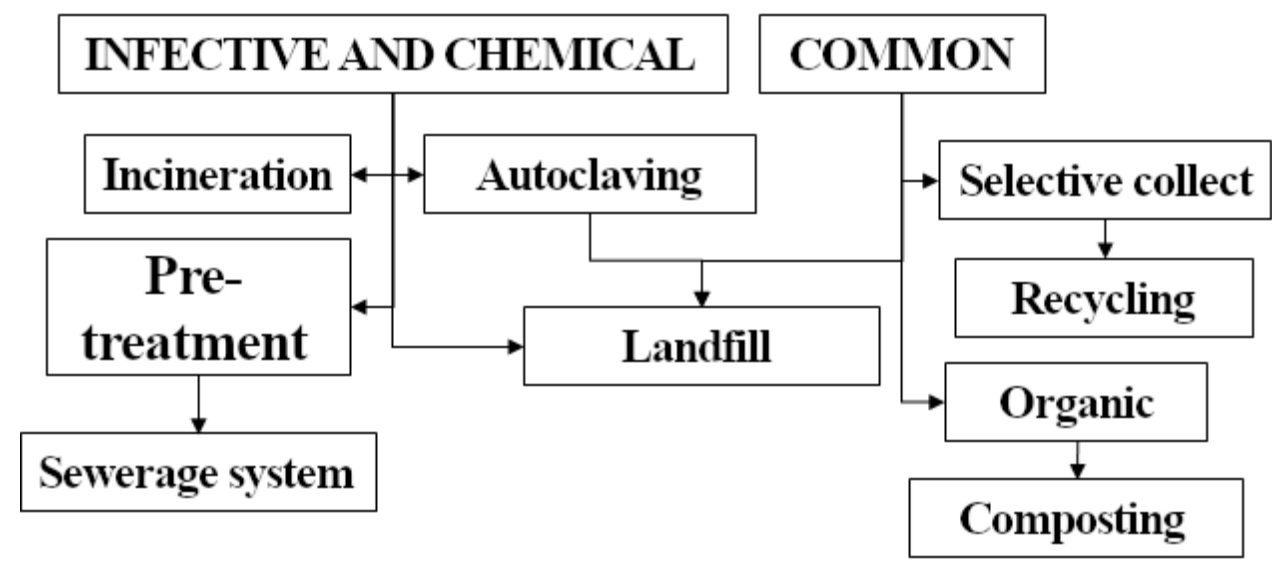

Figure 8. Management collection and external transport.

The procedure in Figure 8 is carried out by third-party companies hired by the establishments themselves, all of which have equipment and vehicles duly equipped and licensed as required by legislation and technical standards for their operation.

The waste identified as infective is directed to autoclaving, incineration or landfill. Chemical residues are previously treated both by the establishments themselves and by third companies. After this treatment, depending on their chemical composition, they will have the same destination as the infecting waste or will be discharged into the sewage system. It is important to highlight that only one establishment has an Effluent Treatment Station (ETE).

The collection and transportation of common waste, those classified as group $D$, are services provided by each AMUREL city hall. According to the parameter of selective collection in the State of Santa Catarina (FECAM, 2019), together with the data collected directly from the municipalities, $50 \%$ of AMUREL's municipalities promote selective collection programs. Only $30 \%$ of the hospitals surveyed have this program at their disposal, with only $20 \%$ actively participating (separating waste) in selective collection.

In 2018, about 5,783 kilos of recyclable waste (paper, plastic and metal) were collected by NGOs and companies that have an agreement with the municipal governments. 
Kitchen oil is collected in $20 \%$ of hospitals by companies that buy it for processing. In 2019, approximately 1,800 liters of fat were acquired from AMUREL hospitals. Organic waste (food leftovers or from its preparation) is collected in $30 \%$ of hospitals by NGOs and composting companies, through formal agreements.

Other waste not collected for recycling and composting is collected by municipal governments and sent to landfills.

\subsection{HSW destination}

Also in the process of external collection and transportation, the final destination of $\mathrm{HSW}$ is also different for infectious, chemical and common waste.

Infectious residues, these classified in group $A$ and $E$, are destined to landfills, using the septic trench technique or incineration. Approximately $32.43 \%$ of the infectious waste is incinerated, $21.35 \%$ in companies that are not located in AMUREL.

All the municipalities in the AMUREL region are served by only one landfill, located in Laguna/SC and currently managed by a private company, which also provides HSW collection and transport services to $70 \%$ of the hospitals surveyed. The closest landfills in the region are Araranguá/SC, Içara/SC and Urussanga/SC. Besides the municipalities of AMUREL, the landfill of Laguna/SC serves five more municipalities in other regions and about 251.16 tons/day are received.

In the landfill, the infectious waste is autoclaved for proper sterilization, eliminating any contaminant agent. After sterilization, the waste is transferred to a specific area of the landfill, separated from the other types of waste, and finally confined.

Common waste (group D) from health facilities, as it is collected together with municipal waste, has the same procedure. When they arrive at the landfill, they are weighed and catalogued according to their municipality of origin. After that, they are sent to the recyclables screening, where they are analyzed and separated according to their composition.

Due to the volume of MSW received at the landfill, approximately $2 \%$ return to the production chain through recycling, forwarding them to various processing and reuse companies.

\subsection{Date analysis}

The analysis of HSW management seeks an integral approach, making a comparison of MSW with HSW. Therefore, questions are presented in a synergic way, using secondary data for such comparison.

According to Pereira et al. (2013), it was estimated that approximately $90.72 \%$ of Group $D$ waste have the possibility of being recycled. With this index, considering the generation rate of Group D waste from the hospitals surveyed $(1.05 \mathrm{~kg} / \mathrm{bag} / \mathrm{day})$, there is a potential of $0.95256 \mathrm{~kg} / \mathrm{bag} /$ day of waste that can be recycled.

As the AMUREL region currently has 921 operational beds, a potential of 877.31 $\mathrm{kg} /$ day and $320,217.33 \mathrm{~kg} / \mathrm{year}$ of raw material is available. The comparison or estimation of economic values is not possible due to the variation of values of recyclable materials (glass, paper, metals, among others).

With the analysis of the data presented and the processes involved in the management of the HSW, we obtained the description of the logistics of the HSW in hospitals in the AMUREL region, which is described in Figure 9. 


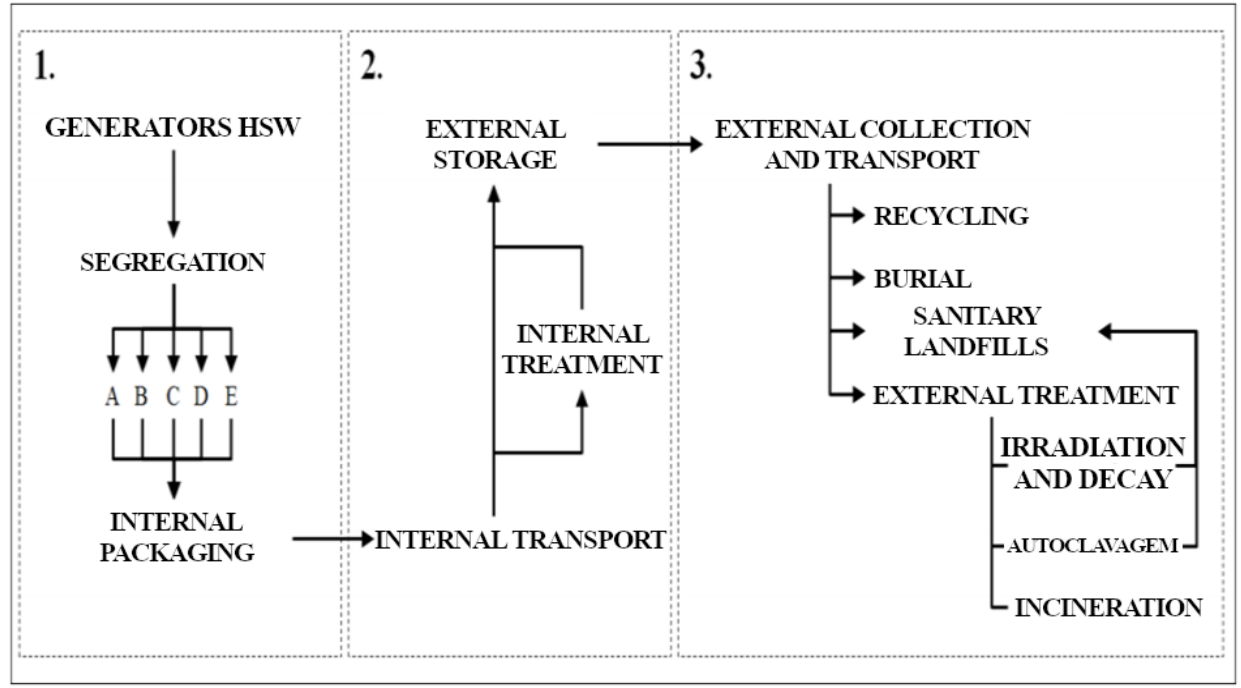

Figure 9. HSW Logistics of the AMUREL region.

As regards the first part of the figure, according to the data obtained through questionnaires and on-site observation, there is great attention to biosecurity, but not to the concern of reducing HSW generation. This does not unfold into actions with the purpose of minimizing environmental impact. Segregation proved to be inefficient, as professionals presented insecurity in classifying waste, which was corroborated by the frequent contact of the establishments to clarify doubts about the HSW, in addition to $30 \%$ stating that there is no segregation of waste in subgroups A1, A2, A3, A4 and A5. About $60 \%$ stated that they mix the waste from group $E$ with the waste from group $A$ for internal or external collection. The segregation of group $B$ and $C$ waste corresponds to the legal precepts according to the rules and legislation in force. The segregation of Group D's waste adequate, however it lacks a greater control as to the verification of contamination in certain materials and the division of the recyclable and non-recyclable ones, being able to provide their reuse. The lack of group A segregation may cause an unnecessary increase in treatment costs, since $70 \%$ of the waste from this group, according to the questionnaire, would not require treatment. Conditioning has proved adequate in $80 \%$ of hospitals.

For Tabrizi et al. (2018), the existence of infectious waste with household waste, also known as public waste, and the lack of separation of medical waste may result in the entry of hazardous waste into the disposal cycle of a particular community or region, causing irreparable environmental damage due to lack of sterilization.

As for the second part, there is adequate equipment for internal transportation, but some establishments use the same equipment for common and HSW waste. It was observed that the collection and internal transport present problems in $60 \%$ of the establishments, for crossing with the route of clean clothes and sterilized material. About $50 \%$ of the establishments do not have adequate external storage, exposing the hospital community to risks and facilitating the access of animals that transmit diseases.

Finally, regarding the third part, in all the researched establishments the collection and the external transport differ from the scheduled time with the service providers and the arrival of the collection vehicle. Better supervision of the waste transportation process of the researched establishments is necessary, due to the impossibility of 
gathering this information from the official agencies. Only $30 \%$ of the establishments have selective collection offered by the municipality. However, only $20 \%$ have the routine of separation of materials for selective collection. It can be affirmed that none of the establishments shows concern with the external environment, where the public services are delegated to third parties, without seeking the knowledge of the destination or the conditions of final destination. Burial is offered directly and easily to the establishments, as well as transportation for this purpose, for returning the parts, since the lifeless bodies do not need extraordinary conditions of transportation. Chemical products receive full attention and adequate treatment in all cases.

In order to have a correct management of the HSW, it is necessary that the people involved are trained in the identification, segregation, transport and correct destination for each group of waste. Although they present an awareness on the part of health teams about the risk of waste, the dissemination and application of technical standards and regular monitoring have been the main concerns, since health worker safety practices are affected by knowledge and training (Aung et al., 2019). Deficient training can cause accidents with extremely dangerous and infected materials, such as punctures, and may not be restricted to those who work in the hospital environment, but also the general population. The professionals involved in the collection and recycling of materials generally lack adequate training and equipment, since there is a low level of knowledge regarding the dangers existing in waste handling, increasing the risk of injuries and infections (Thakur et al., 2018).

Incorrect management will result in the wrong HSW segregation, considering that all waste is contaminated. According to Mahesh Kumar \& Rajesh (2019), segregation, handling, transport and disposal of waste must be adequate, as well as minimizing the risks to the environment and better understanding of its economic value. Thus, investments increase more than necessary for the treatment of the total mass of HSW, besides compromising all other steps for the correct destination of these residues.

\section{Final considerations}

The methodology proposed in this research allowed an evaluation of the practices adopted by hospital institutions in waste management. The proposed methodologies provided us with subsidies that provided a network of information that make up the management framework adopted in the establishments.

Waste from health services has always been a controversial issue in society in general, with several paradigms dealing with this subject. This was extremely evident during the course of this survey, presenting resistance on the part of the participants in answering some questions regarding waste management and its internal practices.

Of all the processes presented, segregation presented a greater need for attention and training for a more efficient HSW management. When done incorrectly, considering that everything is contaminated, it demands investments with treatment of the total mass of HSW, besides providing a drop in the volume of garbage in the environment and requiring fewer investments with infrastructure for disposal of MSW. These investments, in turn, may be directed to improvements in the external storage of hospitals and to the training of teams, offering greater knowledge about the health waste that presented a worrying parameter.

In relation to the impact that the legal norms and the policy have on the management of MSW, the enactment is not enough to guarantee efficient procedures and provide performance indicators, as well as to evidence the efficiency of the methods provided 
for in the legislation and improvements to the environment, the performance of which is recommended for future research. Further information on nuclear waste, with more detailed data on how it is handled by companies in health facilities, is also suggested for future research.

\section{References}

Associação Brasileira de Empresas de Limpeza Pública e Resíduos Especiais - ABRELPE. (2014). National Panorama of Solid Waste 2014. Retrieved in 2018, July 22, from http://www.abrelpe.org.download_2014.php

Associação Brasileira de Empresas de Limpeza Pública e Resíduos Especiais - ABRELPE. (2018). National Panorama of Solid Waste 2018-2019. Retrieved in 2020, May 10, from http://abrelpe.org.br/download-panorama-2018-2019/

Aung, T. S., Luan, S., \& Xu, Q. (2019). Application of multi-criteria-decision approach for the analysis of medical waste management systems in Myanmar. Journal of Cleaner Production, 222, 733-745. http://dx.doi.org/10.1016/j.jclepro.2019.03.049.

Brasil. (1989, 11 de julho). Lei $n^{\circ}$ 7.802, de 11 de Julho de 1989. Dispões sobre a pesquisa, a experimentação, a produção, a embalagem e rotulagem, o transporte, o armazenamento, a comercialização, a propaganda commercial, a utilização, a importação, a exportação, o destino final dos resíduos e embalagens, a classificação, o controle, a inspeção e a fiscalização de agrotóxicos, seus components e afins e dá outras providências. Brasília, DF: Diário Oficial da República Federativa do Brasil.

Brasil. (1990, 19 de setembro). Lei $n^{\circ}$ 8.080, de 19 de Setembro de 1990. Dispõe sobre as condições para a promoção, proteção e recuperação da saúde, a organização e $O$ funcionamento dos serviços correspondentes e dá outras providências. Brasília, DF: Diário Oficial da República Federativa do Brasil.

Brasil. (2002, 8 de janeiro). Decreto $n^{\circ} 4.074$ de 4 de Janeiro de 2002. Regulamenta a Lei no 7.802, de 11 de julho de 1989, que dispõe sobre a pesquisa, a experimentação, a produção, a embalagem e rotulagem, o transporte, o armazenamento, a comercialização, a propaganda comercial, a utilização, a importação, a exportação, o destino final dos resíduos e embalagens, o registro, a classificação, o controle, a inspeção e a fiscalização de agrotóxicos, seus componentes e afins, e dá outras providências.

Brasil. Agência Nacional de Vigilância Sanitária. (2004, 7 de dezembro). Resolução $R D C n^{\circ}$ 306, de 7 de Dezembro de 2004. Dispõe sobre o Regulamento Técnico para o gerenciamento de resíduos de serviços de saúde. Brasília, DF: Diário Oficial da República Federativa do Brasil.

Brasil. (2005, 29 de abril). Resolução CONAMA n 358 de 29 de Abril de 2005. Dispõe sobre o tratamento e a disposição final dos resíduos dos serviços de saúde e dá outras providências. Brasília, DF: Diário Oficial da República Federativa do Brasil.

Brasil. Agência Nacional de Vigilância Sanitária. (2006, 11 de agosto). Resolução - RE $n^{\circ}$ 2.606, de 11 de Agosto de 2006. Dispõe sobre as diretrizes para elaboração, validação e implantação de protocolos de reprocessamento de produtos médicos e dá outras providências. Brasília, DF: Diário Oficial da República Federativa do Brasil.

Brasil. (2008). Decreto $n^{\circ} 6.514$, de 22 de Julho de 2008. Dispõe sobre as infrações e sanções administrativas ao meio ambiente, estabelece o processo administrativo federal para apuração destas infrações, e dá outras providências. Brasília, DF: Diário Oficial da República Federativa do Brasil.

Brasil. (2010a, 2 de agosto). Lei no 12.305 de 02 de Agosto de 2010. Institui a Política Nacional de Residuos Solidos ; altera a Lei no 9.605, de 12 de fevereiro de 1998; e dá outras providências. Brasília, DF: Diário Oficial da República Federativa do Brasil. 
Brasil. (2010b, 23 de dezembro). Decreto $n^{\circ}$ 7.404, de 23 de Dezembro de 2010. Regulamenta a Lei no 12.305, de 2 de agosto de 2010, que institui a Política Nacional de Resíduos Sólidos, cria o Comitê Interministerial da Política Nacional de Resíduos Sólidos e o Comitê Orientador para a Implantação dos Sistemas de Logística Reversa, e dá outras providências. Brasília, DF: Diário Oficial da República Federativa do Brasil.

Ciplet, D. (2006). Na industry blowing smoke (10 reasons why gasification, pyrolysis \& plasma incineration are not "green solutions"). Berkley: GAIA.

Cunha, V., \& Caixeta Filho, J. V. (2002). Gerenciamento da coleta de resíduos sólidos urbanos: estruturação e aplicação de modelo não-linear de programação por metas. Gestão \& Produção, 9(2), 143-161. http://dx.doi.org/10.1590/S0104-530X2002000200004.

DataSUS. (2018). National Register of Health Facilities - CNES. Retrieved on April 15, 2018, from http:tabnet.datasus.gov.br/tabdata/cadernos/sc.htm

Federação Catarinense de Municípios- FECAM. (2019). Associations of Municipalities of Santa Catarina. Retrieved in 2008, April 14, from http://www.fecam.org.br/

Garcia, L. P., \& Zanetti-Ramos, B. G. (2004). Health care waste management: a question of biosafety. Cadernos de Sáude Pública, 20(3), 744-752. PMid:15263985.

Instituto Brasileiro de Geografia e Estatística - IBGE. (2016). IBGE cities. Brasília: IBGE.

Instituto de Pesquisa Econômica Aplicada - IPEA. (2010). Survey on payment for urban environmental services for solid waste management. Brasília: IPEA.

Mahesh Kumar, A. S., \& Rajesh, A. S. (2019). A unique technique for solid waste segregation. International Journal of Trends in Scientific Research and Development, 3(5), 604-607.

Miguel, P. A. C. (2012). Research methodology in production engineering and operations management (2nd ed.). Curitiba: Manual Real.

Pereira, A. L., \& Pereira, S. R. (2011). The reverse logistics chain of health service waste from public hospitals in Minas Gerais: analysis based on the concepts of the new National Policy on Urban Solid Waste. Revista Desenvolvimento e Meio Ambiente, 24(2), 185-199.

Pereira, A. L., Boechat, C. B., Tadeu, H. F. B., Silva, J. T. M., \& Campos, P. M. S. (2013). Reverse logistics and sustainability. São Paulo: Cengage Learning.

Tabrizi, J. S., Rezapour, R., Saadati, M., Seifi, S., Amini, B., \& Varmazyar, F. (2018). Medical waste management in community health centers. Iranian Journal of Public Health, 47(2), 286-291. PMid:29445640.

Thakur, P., Ganguly, R., \& Dhulia, A. (2018). Occupational Health Hazard Exposure among municipal solid waste workers in Himachal Pradesh, India. Waste Management (New York, N.Y.), 78, 483-489. http://dx.doi.org/10.1016/j.wasman.2018.06.020. PMid:32559936. 